\title{
Electroretinography and immunohistochemistry of retina in rabbits treated with sildenafil citrate
}

[Eletrorretinografia e imuno-histoquímica da retina de coelhos tratados com citrato de sildenafil]

\author{
A.V.C. Amaral ${ }^{1}$, G.A. Silva ${ }^{2}$, A.P.A. Costa $^{3}$, K.S. Oliveira ${ }^{3}$, P. Jordão ${ }^{2}$, A.P. Ribeiro ${ }^{4}$, \\ R. Renzo ${ }^{2}$, J.L. Laus ${ }^{2 *}$ \\ ${ }^{1}$ UFG-Jataí - Jataí GO \\ ${ }^{2}$ Unesp-Jaboticabal - Jaboticabal, SP \\ ${ }^{3} \mathrm{UFG}$ - Goiânia, GO \\ ${ }^{4}$ UFMT - Cuiabá, MT
}

\begin{abstract}
Sildenafil citrate is a type-5 phosphodiesterase inhibitor (PDE-5), able to inhibit type-6 phosphodiesterase (PDE-6) as well, providing clinical benefits and paraeffects, some of them potentially related to the retina. The effects of the sildenafil on the retrobulbar and retinal circulation were studied in 27 adult male rabbits of the White New Zealand breed. The electric activity of the retina was evaluated before and at the end of the treatments, and immunohistochemistry studies were conducted. An amplitude increase of the b wave was found in the mixed response of cones and rods after 7 days of treatment with sildenafil citrate. However, in the other evaluations and periods, the values did not differ from the basal ones. Through immunohistochemistry, no significant decrease of the expression of PDE-5 and PDE-6 proteins was observed. Based on the results obtained, it is possible to admit that the sildenafil citrate did not change the expression of PDE-5 and PDE-6, neither the electroretinographic activity of the retina of male rabbits of the White New Zealand breed.
\end{abstract}

Keywords: rabbit, sildenafil citrate, electroretinography, immunohistochemistry

\section{RESUMO}

O citrato de sildenafil é um inibidor da fosfodiesterase do tipo 5 (PDE-5), capaz de inibir também a fosfodiesterase do tipo 6 (PDE-6), proporcionando benefícios clínicos e paraefeitos, alguns deles potencialmente relacionados à retina. Foram estudados efeitos do sildenafil sobre a circulação retrobulbar e a retiniana em 27 coelhos machos adultos, da raça Nova Zelândia Branco. Avaliou-se a atividade elétrica da retina antes e ao término dos tratamentos e realizaram-se estudos à imunoistoquímica. Encontrou-se aumento da amplitude da onda b na resposta mista de cones e de bastonetes, após 7 dias de tratamento com citrato de sildenafil. Entretanto, nas demais avaliações e períodos, os valores não divergiram dos basais. Pela imunoistoquímica, não se observou diminuição significativa da expressão das proteínas PDE-5 e PDE-6. Com base nos resultados obtidos, é possível admitir que o citrato de sildenafil não alterou a expressão de PDE-5 e PDE-6, tampouco, a atividade eletrorretinográfica da retina de coelhos machos da raça Nova Zelândia Branco.

Palavras-chave: coelho, citrato de sildenafil, eletrorretinografia, imuno-histoquímica

\section{INTRODUCTION}

The sildenafil citrate is able to promote vasodilatation in sites where the type-5 phosphodiesterase (PDE-5) is present. PDE-5

Recebido em 12 de março de 2014

Aceito em 19 de junho de 2015

*Autor para correspondência (corresponding author)

E-mail: jllaus@fcav.unesp.br inhibitors may also act by inhibiting the type- 6 phosphodiesterase (PDE-6) in the retina, with occasional complications on the electric activity. Scientific evidence shows that the drug increases the retinal blood circulation, and it is speculated that the event is a consequence of increased blood flow, due to vasodilation, similar to what 
happens within the penis corpus cavernosum sphere (Grunwald et al., 2001; Foresta et al., 2008). Furthermore, it is speculated that the ideal dose for promoting vasodilatation in the retina of dogs and cats could induce changes in the ophthalmic hemodynamics.

The electroretinogram may be used in studies on toxicity to drugs, once it is able to evaluate the retina functionally (Sims, 2007). Among the components of the ERG that are further subject to influences of drug effects, there are a waves (negative depression) and $\mathrm{b}$ waves (positive deflection) (Acland, 1988; Oriá et al., 2004). Wave a results from the activity of cones and rods (Schaeppi and Liverani, 1977). It reflects the negative change in the intracellular load of photoreceptors (hyperpolarization) occasioned by the light evoked and by the closure of the sodium channels of the cell membrane.

The hyperpolarization decreases the activation of neurotransmitters, which activate the bipolar cells. Wave b has controversial origin (Sims, 2007). It is admitted as resulting from the depolarization of the Müller cells and the bipolar cells. By using different frequencies of the (flicker) stimulus intermittency, it is possible to separate the response of cones and rods. Rods are not able to receive stimuli over 15 pulses of light per second. Cones are able to receive them, noticing flicker stimuli from $30 \mathrm{~Hz}$ to $50 \mathrm{~Hz}$ (Sims, 1999; Oriá et al., 2004; Manzano, 2010).

Observations regarding the action of the phosphodiesterase inhibitors on the ocular function have been documented in isolated cases or experimentally, and there are reports that those drugs may change the function of photoreceptors and retinal blood circulation (Donahue et al., 1998; Vobig, 1999; Klotz et al., 1999; Foresta et al., 2008). Under such conditions, changes of the retinal electric activity should be investigated and quali-quantified.

\section{MATERIAL AND METHODS}

The study was conducted at the Ophthalmology Service and the Vision Electrophysiology Laboratory of the Governor Laudo Latel Veterinary Hospital - Agricultural and Veterinary Sciences School of the São Paulo State University, Campus of Jaboticabal, SP, Brazil, and at the Immunohistochemistry
Laboratory of the Animal Pathology Department of the Zootechnics and Veterinary Sciences School of the São Paulo State University, Campus of Botucatu, SP, Brazil.

The research was conducted complying with the standards of the Association for Research in Vision and Ophthalmology - ARVO (National Institutes of Health Publications Nr. 85-23: Revised 1985), under express authorization of the Ethics Committee on the Use of Animals, Campus of Jaboticabal (protocol nr. 05637/10).

The effects of the sildenafil were evaluated in 18 adult male, albino, homozygote rabbits, of the White New Zealand breed, randomly divided into 3 groups of 6 animals, for treatment with the drug at a dose of $3.5 \mathrm{mg} / \mathrm{kg}$ every 24 hours, for 7 , 15 and 30 days and in 9 control animals, totaling 27 individuals. For selecting the animals to compose the research, the Schirmer lacrimal test (Schirmer Tear Test - Ophthalmos Ltda., Brazil), the biomicroscopy with slit lamp (XL-1 Slitlamp $^{\circledR}$ - Shin-Nippon, Japan), the gonioscopy (Koe ppe medium diagnostic lens 18mm), the applanation tonometry (Tono Pen $\mathrm{XL}^{\circledR}$, Medtronic, USA), the indirect binocular ophthalmoscopy (Indirect binocular ophthalmoscope FOH- ${ }^{\circledR}$ - Eyetec S.A., Brazil) and the dyeing test through fluorescein (Fluorescein strips - Ophthalmos Ltda., Brazil) were conducted, as described by Talieri et al. (2006a) and Talieri et al. (2006b).

After 24 hours of the first (basal) electroretinography, the treatment protocols were initiated with sildenafil or placebo. For the control group, $0.9 \%$ saline solution was employed, orally. The electroretinographic evaluations were always conducted at the same time, beginning one hour after the treatments (sildenafil and placebo), on the $7^{\text {th }}, 15^{\text {th }}$ and $30^{\text {th }}$ days of treatment. At the end of the treatments, the animals were submitted to active euthanasia, their eyes were collected and the retinas were evaluated at immunohistochemistry.

For eletroretinography, the animals were anaesthetized by using the association of $8 \mathrm{mg} / \mathrm{kg}$ of midazolam (Injectable Dormonid, Roche, Brazil) and $50 \mathrm{mg} / \mathrm{kg}$ of ketamine (Ketalar, Pfizer, Brazil), intramuscularly. With the animal under anesthesia and cardiorespiratory functions monitored, the pupils were dilated by using $1 \%$ 
tropicamide drops (Tropicamida Colírio ${ }^{\circledR}$, Alcon, Brazil). The flash ERG protocol was used (Narfström et al., 2002):

1. Test for function of rods: the animals were adapted to dark for the period of 20 minutes. The intensity of the flash stimulus was $0.001 \mathrm{~cd} / \mathrm{LOG}$ $-2.5,0.5 \mathrm{~Hz}$ : rods evaluation (total of 4 flashes with interval of $10 \mathrm{sec)} 3$ candelas/LOG 0 , $0.5 \mathrm{~Hz}$ : mixed evaluation of cones and rods (single flash);

2. 10 minutes of adaptation to light (source of light with 30 candelas);

3. Test for function of the cones: $3 \mathrm{~cd} / \mathrm{LOG} 0$, $0.5 \mathrm{~Hz}$ : evaluation of cones (32 flashes) and 3 candelas/LOG $0,30 \mathrm{~Hz}$ : evaluation of cones (stroboscopic flash).

Active euthanasia was conducted with sodium thiopental (Thiopental, Cristália, Brazil) and the eyes were collected. Blocks of paraffin, containing retina segments, were sectioned at $3 \mu \mathrm{m}$ thickness and the cuts were adhered in lamina previously treated with 3-amino-propyltriethoxysilane (Sigma-Aldrich, USA). They were deparaffinized with subsequent washing of Xylol PA (3x) and alcohol, in the following concentrations: absolute alcohol (2x), 90\%, 70\% and $50 \%$, and distilled water. The antigenic recovery was conducted with sodium citrate solution ( $\mathrm{pH} 6.0$ ), in a pressure pan, for 30 minutes. The endogenous peroxidase enzyme was neutralized by using hydrogen peroxide (9\%) for 15 minutes. After washing in PBS solution ( $\mathrm{pH} 7.4)$, the cuts were blocked with regular goat whey (Vectastain Elite Kit ABC Vector Laboratories, USA), for 1hour, at room temperature, in a closed humid system.

The c-GMP monoclonal (sc-21727, Santa Cruz, USA) and anti-NOS polyclonal (NB110-61647, Novus Biological, USA), Anti-PDE5A (ab14672, Abcam, UK) and Anti-PDE6A (ab61820, Abcam, UK) antibodies were incubated for one night in a closed humid system. Biotinylated policlonal (Vectastain Elite Kit ABC - Vector Laboratories, Burlingame, USA) and biotinylated monoclonal (Vectastain
Elite Kit ABC - Vector Laboratories, Burlingame, USA) secondary antibodies were added in the concentration recommended by the manufacturer, remaining in the tissues for 30 minutes, at room temperature, in a closed humid system. The Avidin-biotin-peroxidase complex was added (Vectastain Elite Kit ABC - Vector Laboratories, Burlingame, USA). The reaction was detected by adding diaminobenzidineperoxidase (Dako Cytomation Carpinteria, USA). The counter-staining was conducted with Harris's haematoxyline. The laminas were prepared with the Aquatex media (Merck, Darmstadt, Germany) and evaluated at light microscopy.

For the accounting of the intensity and the percentile of marked cells, the semi-quantitative index was used (Ferioli et al., 2013), according to the following table (Tab. 1):

Table 1. Classification of immune marking per semi-quantitative index

\begin{tabular}{ll}
\hline Index & Marking \\
\hline 0 & Absence of marking \\
1 & Focal marking \\
2 & Up to $25 \%$ of the field marked \\
3 & From 25 to $50 \%$ of the field marked \\
4 & More than $50 \%$ of the field marked \\
5 & More than $75 \%$ of the field marked \\
6 & More than $95 \%$ of the field marked \\
\hline
\end{tabular}

Source: Ferioli et al. (2013). Data were evaluated using the Kolmogorov Smirnov test concerning normality. Analysis of variance for repeated measures, followed by the Bonferroni's post-hoc test, was used in the comparison among the averages. The significance level adopted was $\mathrm{P}<0.05$.

\section{RESULTS}

In the scotopic phase (rods) of electroretinographic study were observed concerning amplitudes $(p=0.22)$ and implicit times $(p=0.07)$ of $b$ wave, and in the periods of adaptation response of the rods, there was no difference among the treatment periods (Fig. 1 and 2 and Tab. 2). 


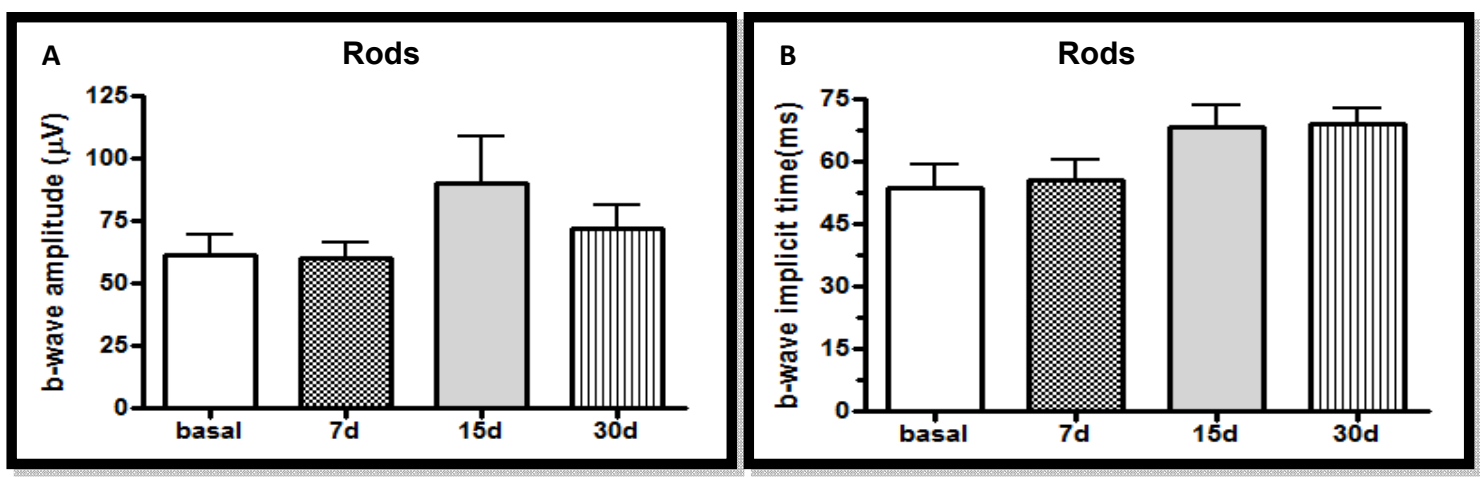

Figure 1. Amplitudes (A) and implicit times (B) of b wave, in the scotopic phase (rods), basal phase and at days 7,15 and 30 of the oral administration of sildenafil $(3.5 \mathrm{mg} / \mathrm{kg})$, in male rabbits of the White New Zealand breed. Jaboticabal, SP, Brazil, 2013.

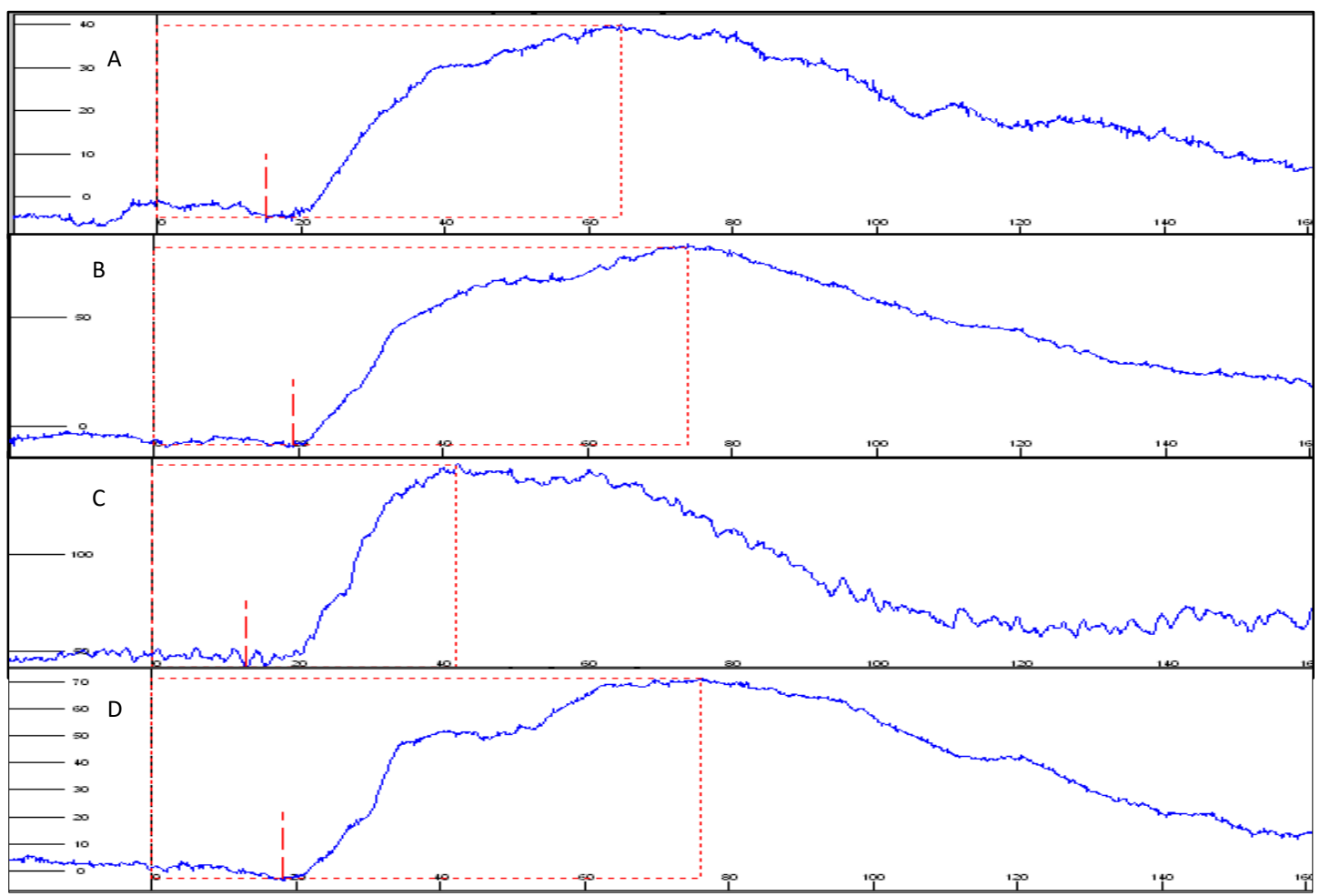

Figure 2. Flash electroretinograms during the scotopic phase, basal (A), 7 (B), 15 (C) and 30 (D) days after the oral administration of sildenafil $(3.5 \mathrm{mg} / \mathrm{kg})$, in male rabbits of the White New Zealand breed. Jaboticabal, SP, Brazil, 2013.

In the high amplitude scotopic phase (cones and rods) of electroretinographic study it was observed that the amplitudes of $a$ and $b$ waves in the animals treated for 7 days were larger, when compared to the basal $(\mathrm{P}=0.04)$. Significant increase in the implicit time of formation of the $b$ wave $(\mathrm{P}=0.02)$ was noticed, when compared to the basal values and the values obtained on the $7^{\text {th }}$ day of treatment (Fig. 3 and 4 and Table 2).

Regarding the ratio between $a$ and $b$ waves, during the high amplitude scotopic phase (cones and rods), no significant differences were observed among the treatment groups. 

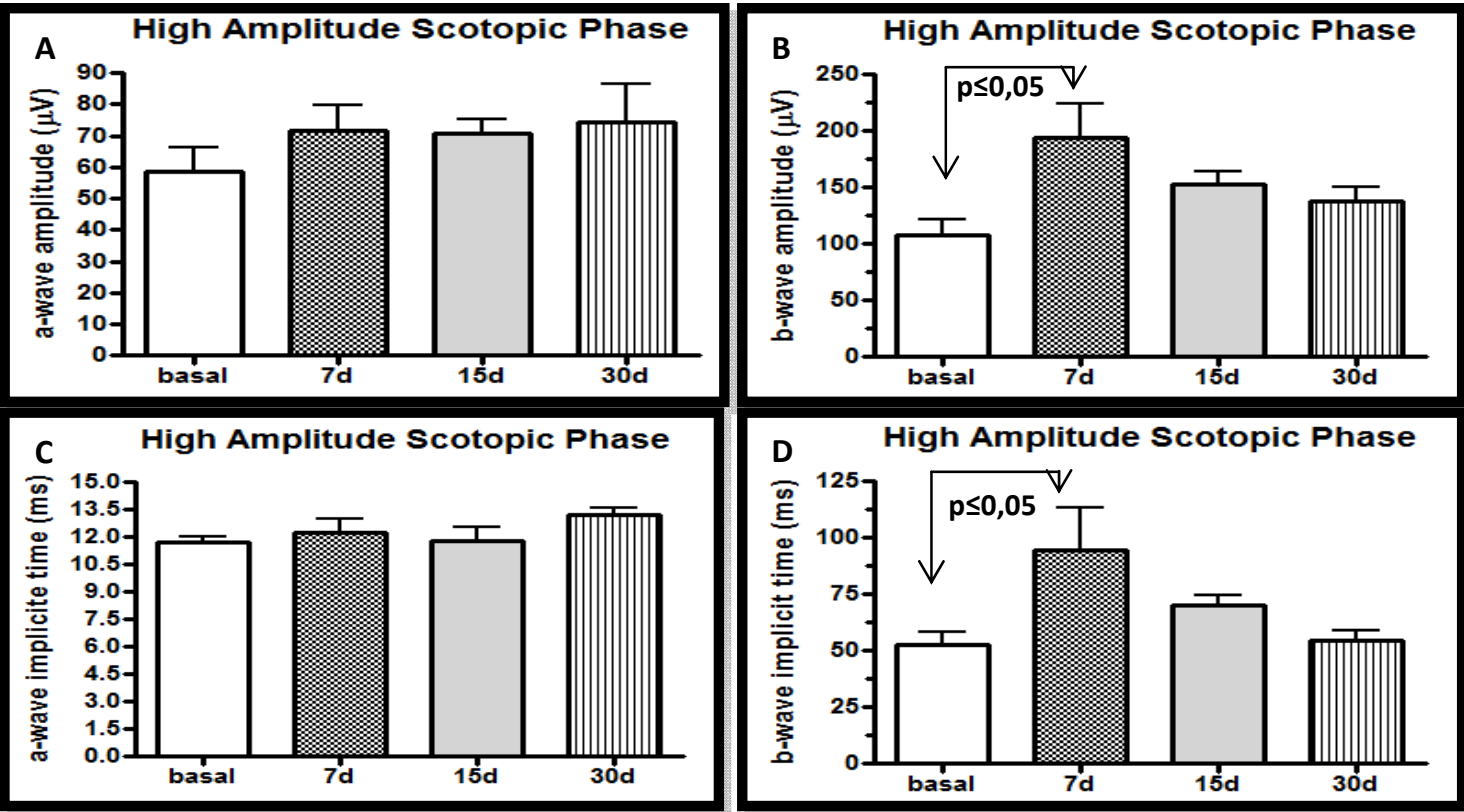

Figure 3. Amplitudes and implicit times of a wave (A and C) and b wave (B and D), during the scotopic phase (cones and rods), basal phase and on days 7,15 and 30 of the oral administration of sildenafil $(3.5 \mathrm{mg} / \mathrm{kg})$, in male rabbits of the White New Zealand breed. Jaboticabal, SP, Brazil, 2013.

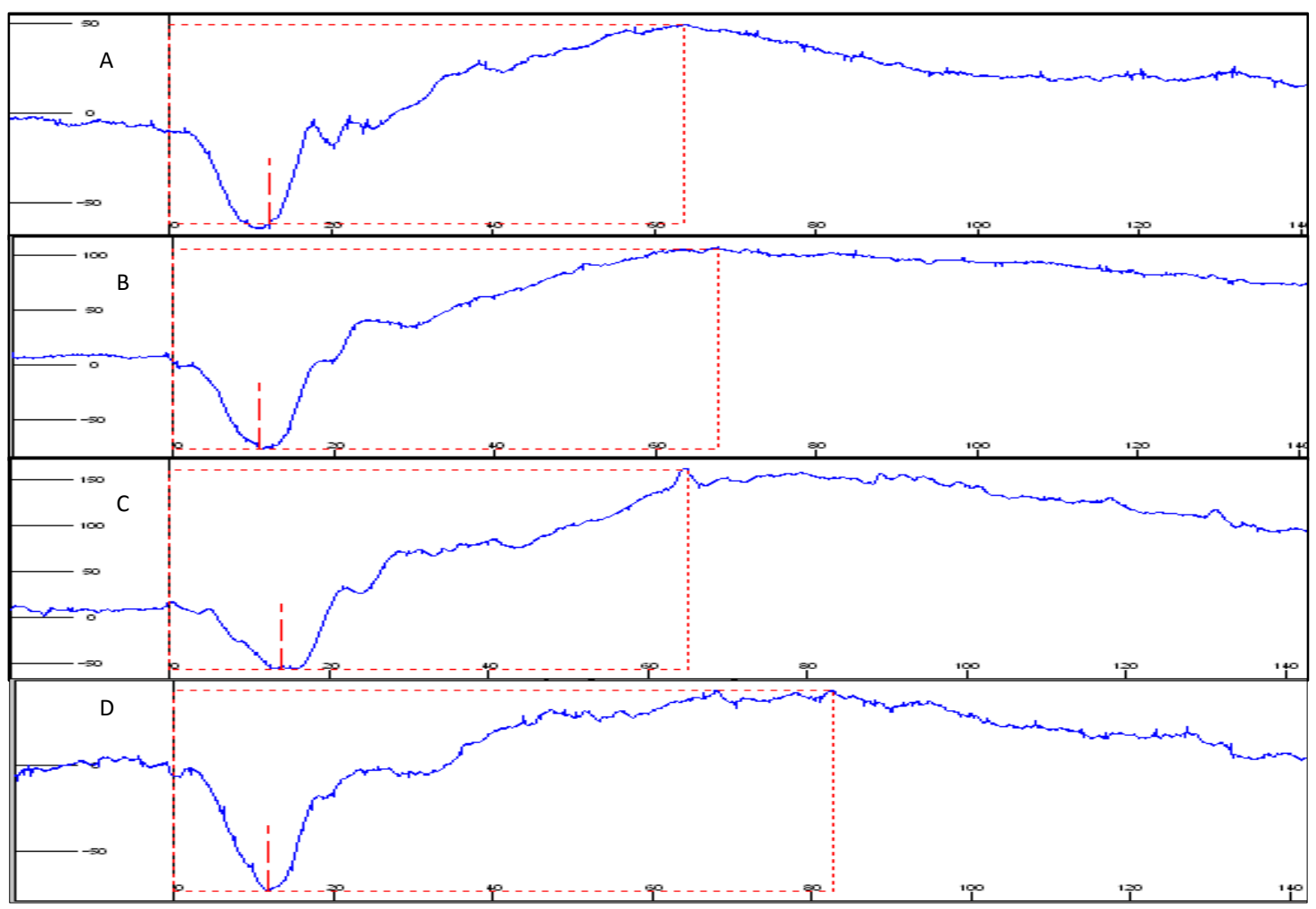

Figure 4. Flash electroretinograms during the scotopic phase (cones and rods), basal phase (A), 7 (B), 15 (C) and 30 (D) days of the oral administration of sildenafil $(3.5 \mathrm{mg} / \mathrm{kg})$, in male rabbits of the White New Zealand breed. Jaboticabal, SP, Brazil, 2013. 
In the photopic phase (cones) of electroretinographic study there was no significant difference among the treatments and respective times, regarding the amplitude $(p=0.80)$ and the implicit time values of $b$ wave $(\mathrm{p}=0.77)$ (Fig. 5 and 6 and Tab. 2).

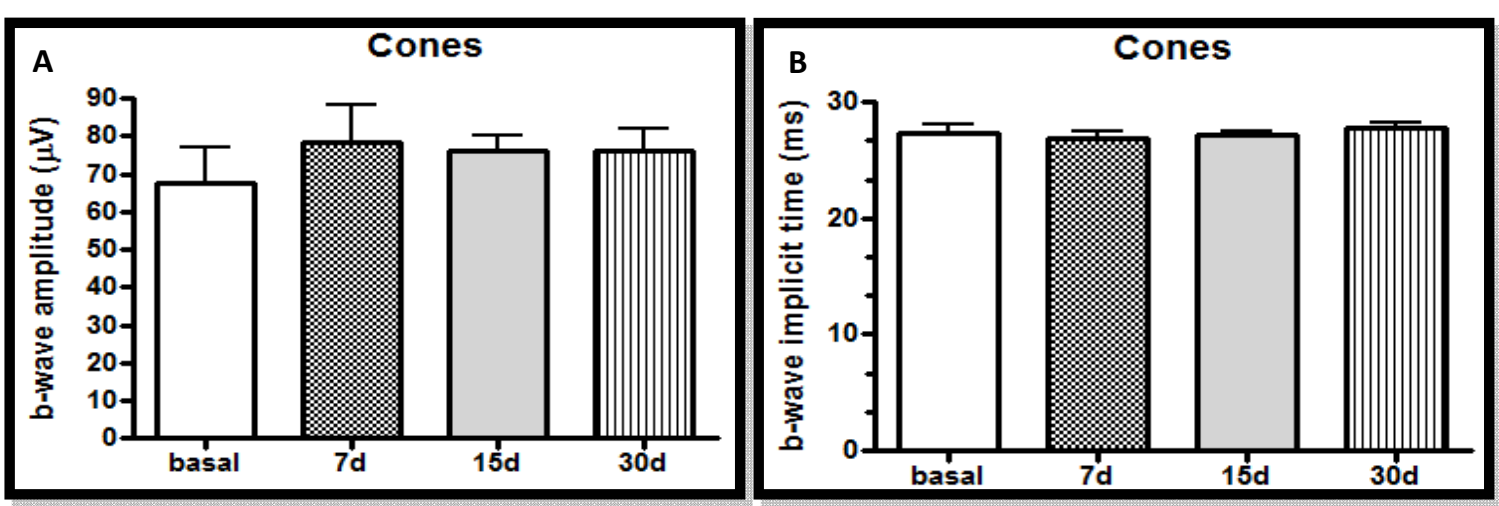

Figure 5. Amplitudes (A) and implicit times (B) of b wave during the photopic phase (cones), basal phase and on days 7, 15 and 30 of the oral administration of sildenafil $(3.5 \mathrm{mg} / \mathrm{kg})$, in male rabbits of the White New Zealand breed. Jaboticabal, SP, Brazil, 2013.

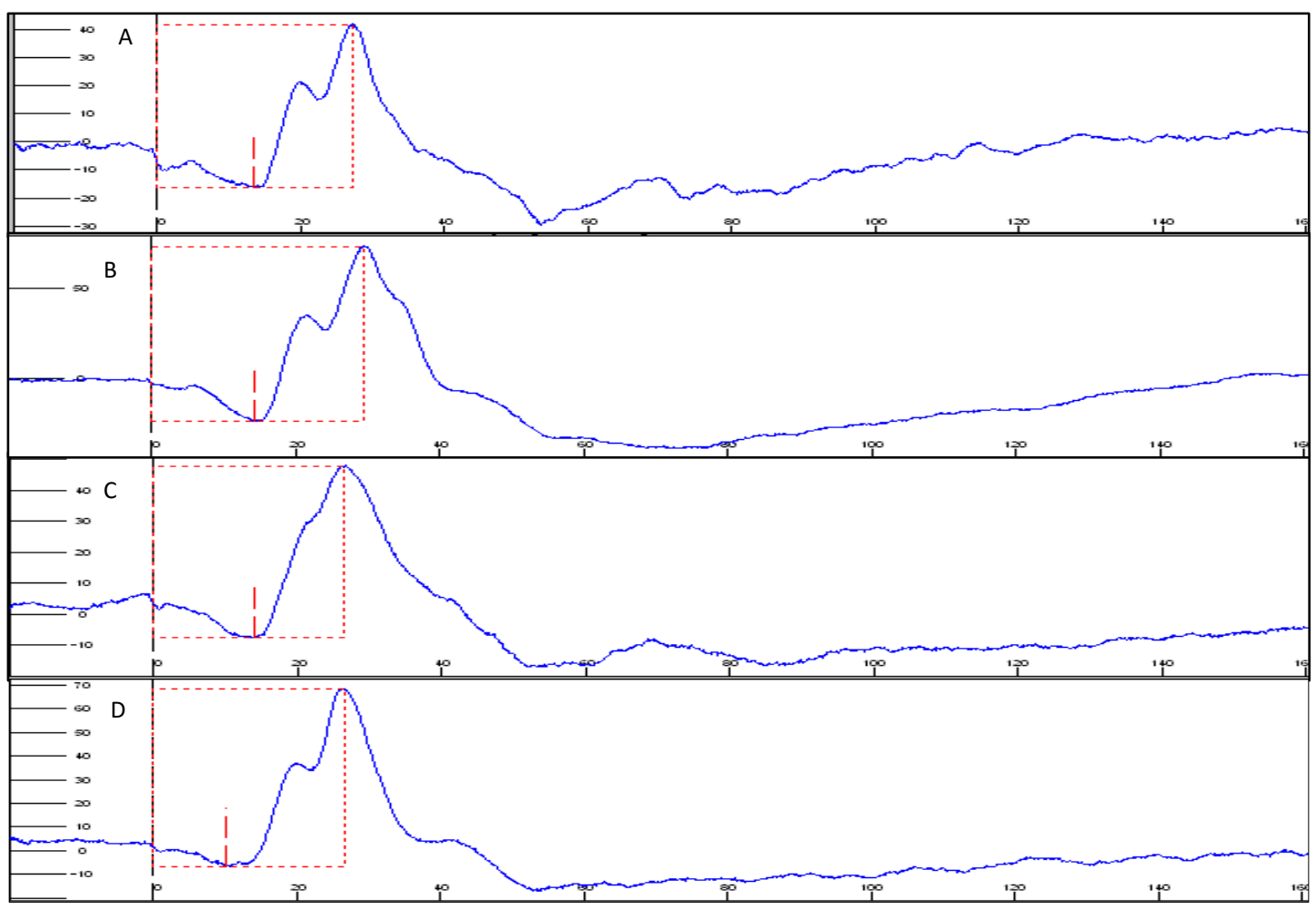

Figure 6. Flash electroretinograms, during the photopic phase (cones), basal phase (A) and on days 7 (B) and $15(\mathrm{C})$ of the oral administration of sildenafil $(3.5 \mathrm{mg} / \mathrm{kg})$, in male rabbits of the White New Zealand breed. Jaboticabal, SP, Brazil, 2013.

In the high intensity photopic phase (flicker cone) of electroretinographic study the amplitude values of the $b$ wave $(p=0.38)$, as well as those of the implicit time $(\mathrm{p}=0.41)$, did not differ among the treatment periods (Fig. 7 and 8 and Tab. 2). 

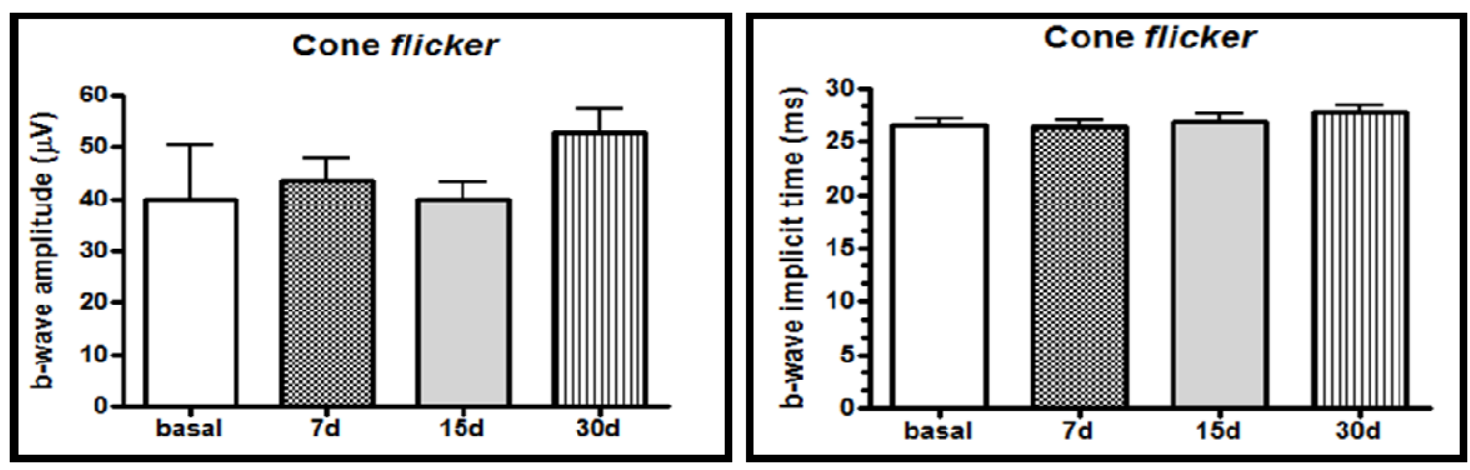

Figure 7. Amplitudes (A) and implicit times (B) of the b wave during the high intensity photopic phase (flicker cone), basal phase and on days 7, 15 and 30 of the oral administration of sildenafil $(3.5 \mathrm{mg} / \mathrm{kg})$, in male rabbits of the White New Zealand breed. Jaboticabal, SP, Brazil, 2013.

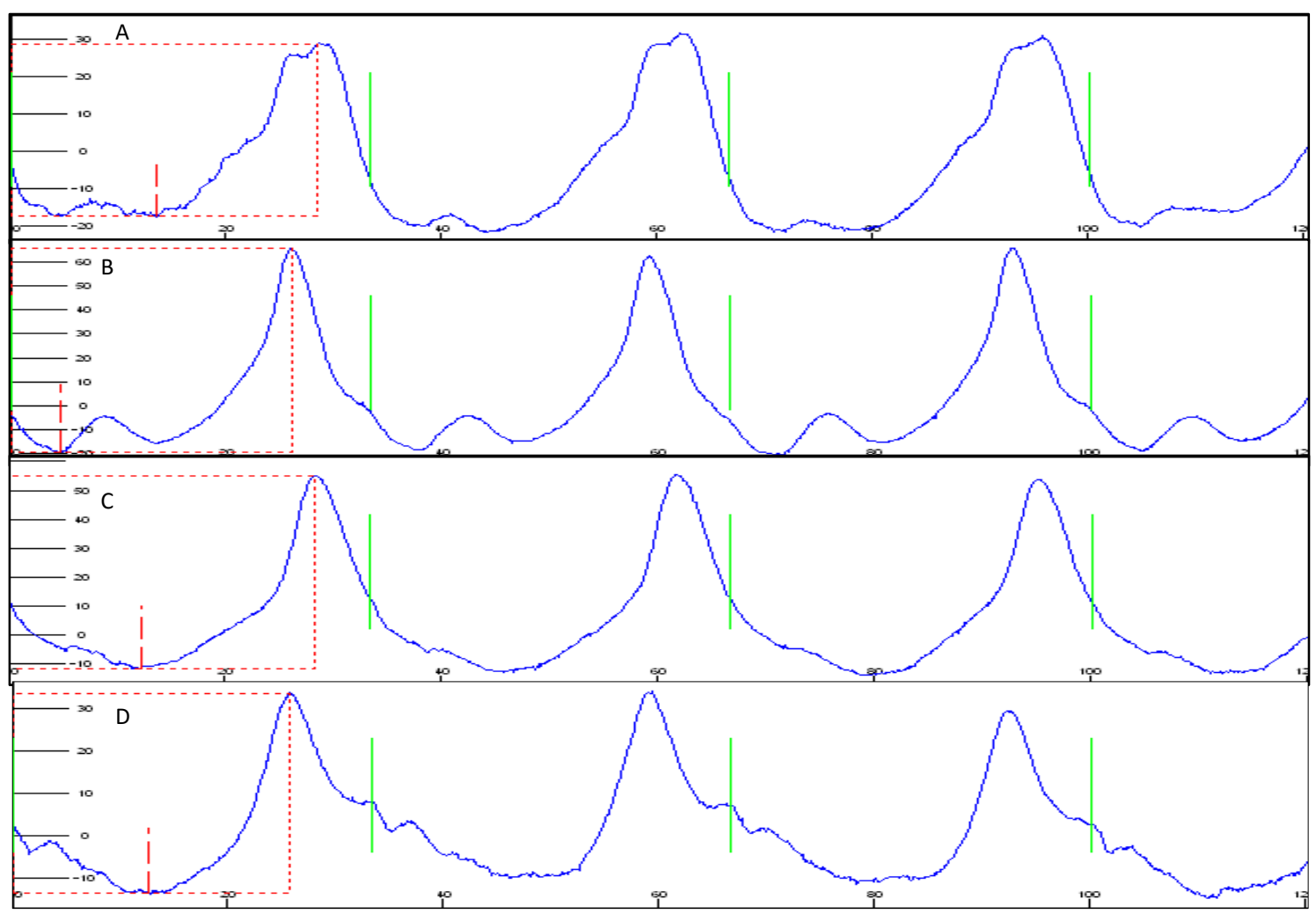

Figure 8. Flash electroretinograms, during the high intensity photopic phase (flicker cone), basal phase (A) and on days 7 (B), 15 (C) and 30 (D) of the oral administration of sildenafil (3.5mg/ $\mathrm{kg})$, in male rabbits of the White New Zealand breed. Jaboticabal, SP, Brazil, 2013.

Immune markings of PDE-5 were noticed in the animals treated, as well as in those that received placebo (control group). The immune marking standard was from focal to $25 \%$ of the microscopic field examined. The cells that expressed the PDE-5 were, notably, those of the layer of ganglion cells (Fig. 9). The expression of the PDE-5 was equally observed in the endothelium of the retinal blood vessels. There was no reduction of the expression of the PDE-5 in the individuals treated with sildenafil citrate, when compared to the control $(\mathrm{P}>0.05)$. The negative control of the PDE-5 (with no primary antibody) did not show immune marking (Fig.10). 
Table 2. Amplitudes and implicit times of the scotopic and photopic phases, basal phase and on days 7, 15 and 30 of the oral administration of sildenafil $(3.5 \mathrm{mg} / \mathrm{kg})$, in male rabbits of the White New Zealand breed. Jaboticabal, SP, Brazil, 2013.

\begin{tabular}{|c|c|c|c|c|c|c|c|c|}
\hline \multirow[t]{2}{*}{ Phase } & \multicolumn{4}{|c|}{ Amplitude $(\mu \mathrm{V})$} & \multicolumn{4}{|c|}{ Time (miliseconds) } \\
\hline & Basal & Day 7 & Day 15 & Day 30 & Basal & Day 7 & Day 15 & Day 30 \\
\hline Rods & $61.3 \pm 7.9$ & $59.3 \pm 6.6$ & $90.3 \pm 18.5$ & $71.8 \pm 9.4$ & $53.6 \pm 5.6$ & $55.5 \pm 4.9$ & $68.2 \pm 5.2$ & $68.9 \pm 3.7$ \\
\hline $\begin{array}{l}\text { Scotopic Phase } \\
\text { (a-wave) }\end{array}$ & $58.5 \pm 7.6$ & $71.7 \pm 7.8$ & $70.5 \pm 4.7$ & $74.2 \pm 12.5$ & $11.7 \pm 0.3$ & $12.2 \pm 0.7$ & $11.7 \pm 0.8$ & $13.2 \pm 0.4$ \\
\hline $\begin{array}{l}\text { Scotopic Phase } \\
\text { (b-wave) }\end{array}$ & $107.2 \pm 13.9$ & $194.0 \pm 29.9$ & $152.3 \pm 11.8$ & $138.0 \pm 11.9$ & $52.6 \pm 5.8$ & $94.6 \pm 18.4$ & $70.1 \pm 4.3$ & $54.3 \pm 4.6$ \\
\hline Cones & $67.5 \pm 9.5$ & $78.2 \pm 10.1$ & $76.3 \pm 3.9$ & $76.2 \pm 5.7$ & $27.3 \pm 0.7$ & $26.9 \pm 0.5$ & $27.2 \pm 0.3$ & $27.7 \pm 0.4$ \\
\hline Flicker & $40.0 \pm 10.4$ & $43.6 \pm 3.9$ & $39.8 \pm 3.5$ & $52.8 \pm 4.4$ & $26.6 \pm 0.5$ & $26.4 \pm 0.5$ & $26.8 \pm 0.7$ & $27.8 \pm 0.5$ \\
\hline
\end{tabular}

The expression of the PDE- 6 was observed in the layer of photoreceptors and in the layer of ganglion cells (Fig. 9). There was no significant difference in the immune marking standard when compared to the groups treated and the control group $(\mathrm{P}>0.05)$. The expression of the PDE-6 was detected, in average, in 25 to $50 \%$ of the microscope fields examined. Negative controls of the PDE-6 (with no primary antibody) did not show immune marking (Fig. 10).
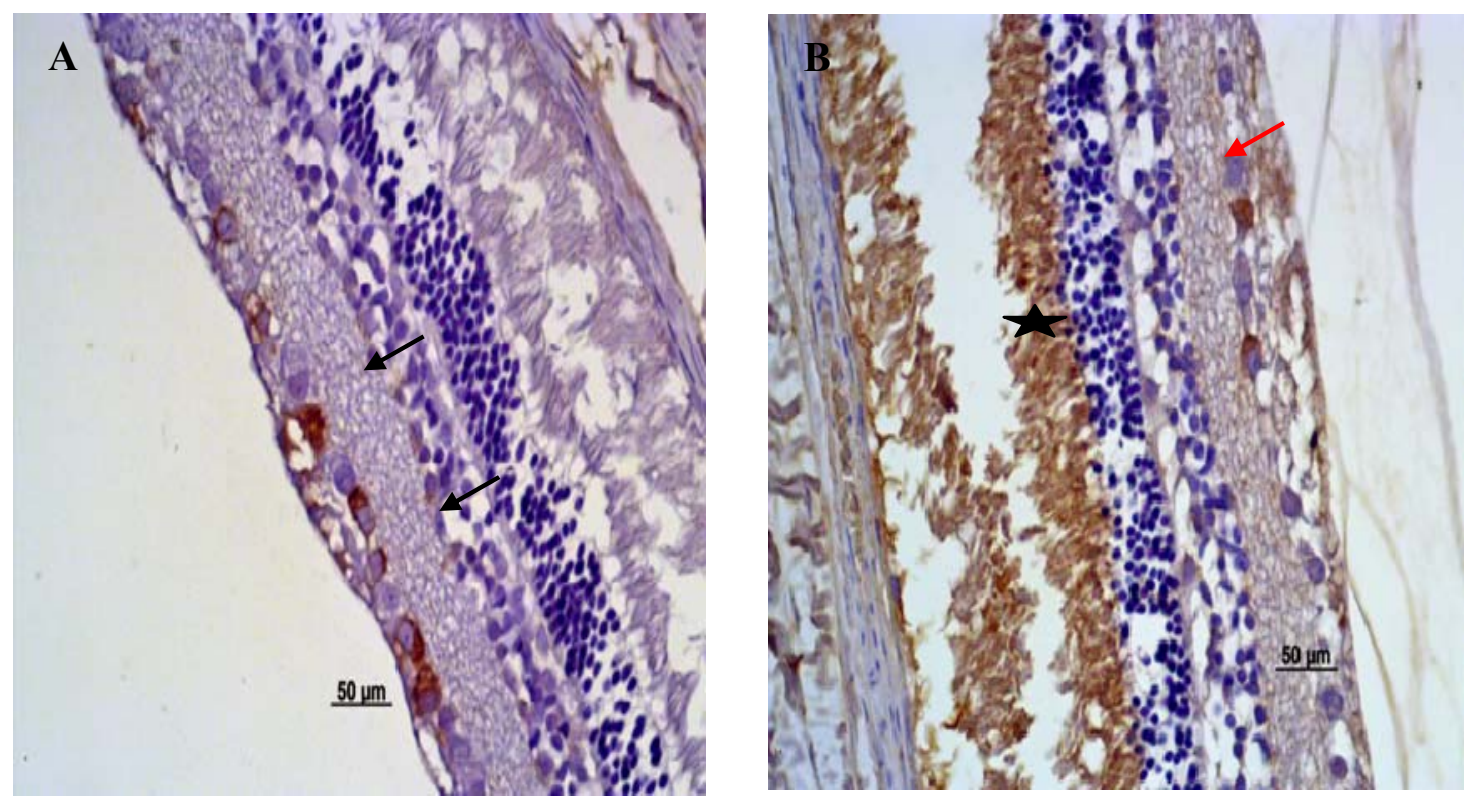

Figure 9. Immune marking of the expression of the PDE-5 (A) in ganglion cells (black arrows) on day 30 and of the PDE-6 (B) in ganglion cells (red arrow) and in photoreceptors (star) on day 15 of treatment with sildenafil citrate $(3.5 \mathrm{mg} / \mathrm{kg})$, in male rabbits of the White New Zealand breed. Jaboticabal, SP, Brazil, 2013. 

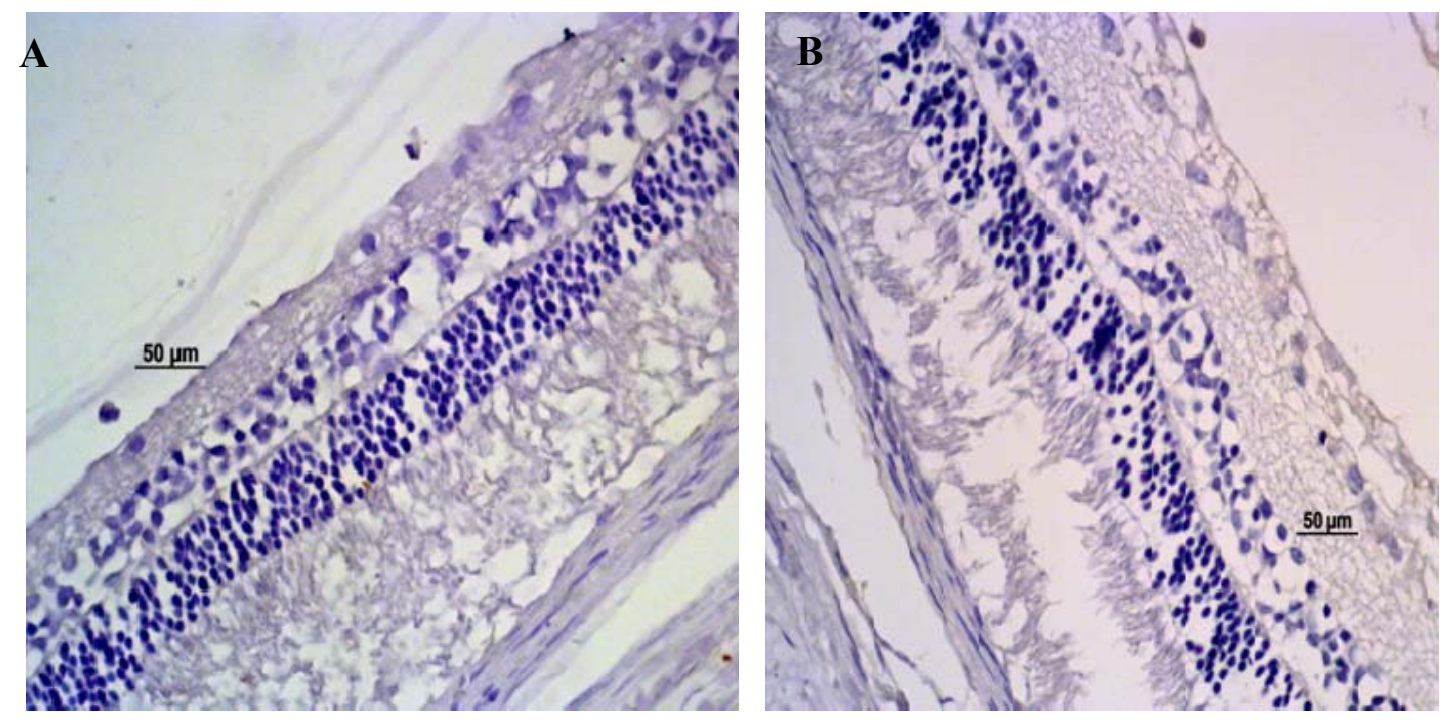

Figure 10. Negative control of the expression of the PDE-5 (A) on day 30 of treatment and of the PDE-6 (B) on day 15 of treatment with sildenafil citrate $(3.5 \mathrm{mg} / \mathrm{kg})$, in male rabbits of the White New Zealand breed. Jaboticabal, SP, Brazil, 2013.

\section{DISCUSSION}

According to Manzano (2010), there are ophthalmic, anatomic and functional particularities in rabbits regarding the ERG, the administration and the response to the drug action. Although the retina of the rabbits does not show taint, the amount of cones is able to generate electric response to stimuli. In the retina of those animals, the rods prevail over the cones.

The electroretinogram may be used in studies on toxicity to drugs, once it is able to evaluate the retina functionally (Sims, 2007). However, difficulties were found in localizing reference values in rabbits, due to the variability of methods and protocols (Manzano, 2010). Thus, in this study, the comparison of the results on the treatment with sildenafil citrate was conducted with the basal of the individuals themselves.

Significant increase in the amplitude and in the implicit time of $b$ wave of the mixed response of cones and rods was evidenced in animals treated for 7 days with sildenafil citrate. However, in the other evaluations and periods, the values did not differ from the basal ones. The changes in the electroretinographic outlines may be attributed to the inhibitory action of sildenafil citrate on PDE6. PDE-5 inhibitors, such as sildenafil citrate, present ten times more affinity with the PDE-5, compared to the PDE-6. Even though effects arising from the inhibition of the PDE-6 were observed (Foresta et al. 2008). The reduction in the amplitude of the $b$ wave is the electroretinographic expression of higher frequency, when the retinal toxicity to drugs is studied (Manzano, 2010), and although not detected in this study, it was evidenced by other researchers in human patients (Klotz et al., 1999; Vobig, 1999).

Klotz et al. (1999) investigated, in human beings, the effects of sildenafil on visual acuity, after the administration of a single dose of $100 \mathrm{mg}$. No changes were found in the visual field, in the vision of colors and concerning the potential evoked. The same authors discoursed, however, about the significant reduction in the amplitude of $a$ and $b$ waves, after one hour of the administration of the drug, and the recovery of the regular functions was observed after six hours. Vobig (1999) informed about the decrease in the electric function, from 30 to $50 \%$, which persisted for about five hours, after the administration of a high dose of sildenafil citrate.

The expression of PDE-5 and PDE-6 was observed in all individuals evaluated in this study. Foresta et al. (2008) showed that the enzyme PDE-5 has different distribution, concerning the PDE-6, in the retina. It was shown that the PDE-6 is expressed in tissues of the human retina (by Western blot), being 
localized in cones and rods, where they play a role in the visual transduction (of low intensity and high gain of signal amplification). The enzyme PDE-5 showed higher expression in retina and choroid vessels. The presence of the PDE-5 in the layer of bipolar cells was documented (Foresta et al., 2008).

The cGMP concentrations in photoreceptors vary along the day, with exposure to light. Animals and human beings without a functional gene for the PDE-6 tend to develop retinal degeneration (Zoumalan et al., 2009). The reasoning is that the chronic suppression of the PDE-6 is possible, i.e., by prolonged treatments with inhibitor drugs, and it could induce to the retinal toxicity. However, in this study, no signs of toxicity were verified.

\section{CONCLUSIONS}

Based on the results obtained and on the way the research was designed, it is possible to admit that the sildenafil citrate did not change the expression of the PDE-5 and PDE-6, or the electroretinographic activity of the retina of male rabbits of the White New Zealand breed.

\section{ACKNOWLEDGMENTS}

To the Foundation for Research Support of the State of São Paulo (FAPESP) (case nr. 2010/00050-0) and the National Council for Scientific and Technological Development (CNPq) (case nr. 300833/2010-5).

\section{REFERENCES}

ACLAND, G.M. Diagnosis and differentiation of retinal diseases in small animals by electroretinography. Semin. Vet. Med. Surg. (Small Anim.), v.3, p.15-27, 1988.

DONAHUE, S. P.; TAYLOR, R. J. Pupil-sparing third nerve palsy associated with sildenafil citrate (Viagra). Am. J. Ophthalmol., v. 126, p.476-477, 1998.

FERIOLI, R.B.; TORRES NETO, R.; COSTA, S.S. et al. Relação da expressão de fatores de crescimento celular (IGF-1) e SCF com fatores prognósticos e o alvo da rapamicina em mamiferos (m-TOR) em mastocitomas cutâneos caninos. Pesquisa Vet. Brasil., v.33, p.549-556, 2013.
FORESTA, C.; CARETTI, A.N.; ZUCCARELLO, D. et al. Expression of the PDE5 enzyme on human retinal tissue: new aspects of PDE5 inhibitors ocular side effects. Eye, v.22, p.144-149, 2008.

GRUNWALD, J.E.; SIU, K.K.; JACOB, S.S. et al. Effect of sildenafil citrate (Viagra) on the ocular circulation. Am. J. Ophthalmol., v.131, p.751-755, 2001.

KLOTZ, T.; VOBIG, M.; WALTER, P. et al. Acute retinal side effects of a single dose of $100 \mathrm{mg}$ sildenafil. J. Urol., v.161, p.215-216, 1999.

MANZANO,R. P.A. Estudo da toxicidade do adalimunabe (Humira $\left.{ }^{\circledR}\right)$ intravítreo para a retina de coelhos. 2010. 130f. Tese (Doutorado) Faculdade de Medicina, Universidade de São Paulo, São Paulo, SP.

NARFSTRÖM, K.; EKESTEN, B.; ROSOLEN, S.G.et al. Guidelines for clinical electroretinography in the dog. Doc. Ophthalmol., v.135, p.83-92, 2002.

ORIÁ, A.P.; LAZARO JÚNIOR, L.P.; HONSHO, C.S. et al. Considerations about electroretinography in dogs. Cienc. Rural, v.34, p.323-328, 2004.

SCHAEPPI, U.; LIVERANI, F. Procedures for routine clinical electroretinography (ERG) in dogs. Agents Actions, v.3, p.347-351, 1977.

SIMS, M.H. Electrodiagnostic evaluation of vision. In: GELATT, K.N. Veterinary ophthalmology. 4.ed. Philadelphia: Lippincott Williams \& Wilkins, 2007. p.483.

SIMS, M.H. Eletrodiagnostic evolution of vision. In: GELATT, K.N. Veterinary ophthalmology. 3.ed. Philadelphia: Lippincott Williams \& Wilkins, 1999. p. 483-510.

TALIERI, I.C.; BRUNELLI, A.T.J.; ORIÁ, A.P. et al. Exame oftálmico em cães e gatos. Clin. Vet., n.61, p.42-54, 2006a.

TALIERI, I.C.; BRUNELLI, A.T.J.; ORIÁ, A.P. et al. Técnicas avançadas no exame oftálmico de cães e gatos. Clin. Vet., n.62, p.40-44, 2006 b.

VOBIG, M.A. Retinal side-effects of sildenafil. Lancet, v.353, p.1442-1443, 1999.

ZOUMALAN, C.I.; ZAMANIAN, R.T.; DOYLE, R.L. et al. ERG evaluation of daily, high-dose sildenafil usage. Doc. Ophthalmol., v.118, p.225$231,2009$. 